\title{
MODEL TREFFINGER: PENGARUH TERHADAP MOTIVASI BELAJAR DAN KEMAMPUAN BERPIKIR KREATIF PADA MATERI BUNYI
}

\author{
Nilawati Tadjuddin ${ }^{1}$, Mukarramah Mustari², Mela Puspita ${ }^{3 *}$ \\ ${ }^{1}$ Pendidikan Guru Raudhatul Anfal, Universitas Islam Negeri Raden Intan Lampung \\ ${ }^{2}$ Pendidikan Fisika, Universitas Negeri Semarang \\ ${ }^{3}$ Pendidikan Fisika, Universitas Islam Negeri Raden Intan Lampung \\ *corresponding author: puspitamela.96@gmail.com
}

Article History:

Received: januari 11, 2020

Revised: januari 29, 2020

Accepted: april 20, 2020

Published: juni 30, 2020

Keywords: Model Treffinger, Motivasi Belajar, Berpikir Kreatif

\begin{abstract}
This research aims to determine the influence of students learning motivation using the Treffinger learning model and to determine the influence of students' creative thinking skills using the Treffinger learning model. This research was conducted at SMPN 2 Jati Agung, South Lampung. The research method used was quasi-experimental. In taking the sample in this study using a purposive sampling technique, with class VIII $A$ as an experimental class and class VIII B as a control class. The instruments in this research used learning motivation questionnaires and essay tests on creative thinking skills. Research results obtained using the t-test revealed the average score of the students' learning motivation questionnaire in the experimental class is 87.6 and in the control class is 80.0, so that a score of $t_{\text {count }}>t_{\text {table }}(6.019>1.996)$, and the average posttest score of students' creative thinking skills in the experimental class is 80.3 and in the control class is 61.0, so that the score of $t_{\text {count }}>t_{\text {table }}(7.589>1.996)$. It was concluded that there was an influence of Treffinger's learning model on the sound subject on students' learning motivation and students' creative thinking skills.
\end{abstract}

\begin{abstract}
Abstrak: Penelitian ini bertujuan untuk mengetahui pengaruh motivasi belajar peserta didik menggunakan model pembelajaran Treffinger dan untuk mengetahui pengaruh kemampuan berpikir kreatif peserta didik menggunakan model pembelajaran Treffinger. Penelitian ini dilakukan di SMPN 2 Jati Agung Lampung Selatan. Metode penelitian yang digunakan adalah quasi eksperimen. Pengambilan sampel pada penelitian ini menggunakan teknik purposive sampling, dengan kelas VIII A sebagai kelas eksperimen dan kelas VIII B sebagai kelas kontrol. Instrumen dalam penelitian ini menggunakan kuesioner motivasi belajar dan tes kemampuan berpikir kreatif berupa soal essay. Hasil penelitian yang diperoleh dengan menggunakan uji-t skor rata-rata kuesioner motivasi belajar peserta didik kelas eksperimen 87,6 dan kelas kontrol 80,0 diperoleh nilai $t_{\text {hitung }}>\mathrm{t}_{\text {tabel }}(6,019>1,996)$, dan skor rata-rata postest kemampuan berpikir kreatif peserta didik kelas eksperimen 80,3 dan kelas kontrol 61,0 diperoleh nilai thitung $>t_{\text {tabel }}(7,589>1,996)$. Disimpulkan bahwa terdapat pengaruh model pembelajaran Treffinger pokok bahasan bunyi terhadap motivasi belajar dan kemampuan berpikir kreatif peserta didik.
\end{abstract}

\section{PENDAHULUAN}

Salah satu tantangan pada abad ke-21 yaitu pengetahuan, Sumber daya manusia (SDM) dituntut untuk memiliki beberapa pengetahuan yang berkualitas (Harjono, Makhrus, Savalas, \& Rasmi, 2019;
Wijaya, Sudjimat, \& Nyoto, 2016). Peningkatan kualitas SDM menjadi Langkah penting yang harus dilakukan. Usaha peningkatkan kualitas manusia dapat berupa pendidikan (Irwandani, Latifah, Asyhari, Muzannur, \& 
Widayanti, 2017). Pendidikan yang berkualitas membutuhkan proses belajar (Krismiyati, 2017; Maula \& Edwar, 2014).

Kegiatan pembelajaran bagian yang paling pokok pada proses belajar. Dua hal yang perlu di perhatikan pada proses belajar yaitu pengaturan proses belajar mengajar yang baik dan cara pengajaran. Keduanya saling ketergantungan, jika keduanya berjalan dengan baik maka dapat menciptakan suasana belajar yang dapat membuat peserta didik lebih termotivasi untuk belajar (Irwandani \& Rofiah, 2015). Adapun beberapa penelitian mengungkapkan bahwa motivasi peserta didik sangat mempengaruhi hasil belajar (Idris, 2016; Rita, 2019; Silvana \& Sumbawati, 2017; Supriyono, 2018). Setiap pendidik menyadari bahwa dalam proses pembelajaran selalu ada peserta didiknya yang mengalami kesulitan dalam belajar (Rofiqah, Widayanti, \& Rozaqi, 2020). Kesulitan terjadi karena setiap peserta didik mempunyai kemampuan intelektual yang berbeda-beda (Mamangkey, Tewal, \& Trang, 2018), sehingga dalam proses pembelajaran setiap peserta didik berbeda dalam memahami materi pelajaran, salah satunya mata pelajaran fisika.

Ilmu gejala-gejala alam dan ilmu yang paling dasar dari ilmu alam dapat dipelajari pada fisika (Wahyuni, Sutarto, \& I Ketut Mahardika, 2015). Bunyi salah satu materi yang dipelajari pada fisika. Adanya bunyi akan mempermudah memahami gejala alam yang terjadi.

Memahami konsep materi akan lebih mudah jika menemukan konsep itu sendiri (Dewi, 2016). Maka pendidik harus lebih menekankan peserta didiknya untuk berperan aktif dalam proses pembelajaran. Memilih model pembelajaran kunci yang utama untuk membuat peserta didik dapat berperan aktif. Beberapa penelitian menyatakan bahwa aktifnya peserta didik dapat menstimulus pemikiran kreatif peserta didik (G. J. Hwang, Sung, \&
Chang, 2017; G. Hwang, Sung, \& Chang, 2016; Tanti, Jamaluddin, \& Syefrinando, 2017).

Model pembelajaran yang dapat menunjang berpikir kreatif sangat banyak (Noviyana, 2017; Samsudin, Suhandi, Rusdiana, Kaniawati, \& Costu, 2016; Widiana \& Hernadi, 2018). Salah satunya model Treffinger (Annuuru, Johan, \& Ali, 2017). Selain itu, model Treffinger bersifat developmental dan lebih mengutamakan segi proses (Idrus Alhaddad, 2014), sehingga motivasi peserta didik sangat diutamakan. Fokus penelitian ini motivasi belajar peserta didik dapat meningkat yang akan berdampak pada berpikir kreatif peserta didik yang lebih baik.

\section{METODE PENELITIAN}

Penelitian ini menggunakan metode kuasi eksperimen. Menggunakan desain nonequivalent control group design. Desain penelitian di tampilkan pada Tabel 1 berikut (Sugiyono, 2014):

Tabel 1. Desain Penelitian Nonequivalent Control Group Design

\begin{tabular}{lccc}
\hline Kelas & Pretest & Perlakuan & Posttest \\
\hline Eksperimen & $\mathrm{O}_{1}$ & $\mathrm{X}_{1}$ & $\mathrm{O}_{2}$ \\
\hline Kontrol & $\mathrm{O}_{3}$ & $\mathrm{X}_{2}$ & $\mathrm{O}_{4}$ \\
\hline
\end{tabular}

Keterangan :

$\mathrm{O}_{1} \quad$ : Pretest kelas eksperimen

$\mathrm{O}_{2} \quad$ : Posttest kelas eksperimen

$\mathrm{X}_{1} \quad$ : Perlakuan dengan menggunakan model Treffinger

$\mathrm{X}_{2} \quad$ : Perlakuan dengan menggunakan model konvensional

$\mathrm{O}_{3} \quad$ : Pretest kelas kontrol

$\mathrm{O}_{4} \quad$ : Posttest kelas kontrol

Populasi dalam penelitian ini adalah seluruh peserta didik kelas VIII SMP Negeri 2 Jati Agung Tahun ajaran 2017/2018. Adapun sampel yang digunakan dipilih dengan teknik 
purposive sampling sehingga diperoleh dua kelompok yaitu kelas eksperimen dan kelas kontrol.

Prosedur penelitian menggunakan empat tahapan yaitu pendahuluan, persiapan, pelaksanaan dan analisis. Kegiatan pada tahap pendahuluan dilakukan studi lapangan di kelas VIII yang akan menjadi subjek penelitian dan wawancara dengan guru. Setelah diperoleh permasalahan, kemudian menganalisis masalah tersebut. Selanjutnya melakukan studi literatur untuk mencari dan menyusun langkah penyelesaian masalah tersebut.

Kegiatan pada tahap persiapan yaitu penyusunan instrumen penelitian yaitu membuat rencana pelaksanaan pembelajaran (RPP), lembar kerja siswa, kuesioner motivasi belajar sebanyak 25 pernyataan dengan item positif dan item negatif, test kemampuan berpikir kreatif bentuk essay sebanyak 15 butir soal dan lembar observasi. Kemudian melakukan validasi instrumen penelitian RPP, kuesioner motivasi belajar, soal essay kemampuan berpikir kreatif dan lembar observasi. Selanjutnya melakukan uji coba instrumen penelitian soal essay kemampuan berpikir kreatif. Diperoleh 8 butir soal yang layak digunakan untuk penelitian dari 15 butir soal yang diujicobakan.

Kegiatan pada tahap pelaksanaan, setelah semua perangkat dan instrumen penelitian telah siap maka dilakukan penelitian. Kegiatan penelitian dilaksanakan di kelas eksperimen dan kelas kontrol, dengan memberikan pretest dan posttest.

Kegiatan pada tahap analisis yaitu melakukan perhitungan $N$-gain dari nilai pretest dan nilai posttest terhadap motivasi belajar dan kemampuan berpikir kreatif peserta didik pada kelas eksperimen dan kelas kontrol. Data-data tersebut kemudian diuji secara statistik dan ditelaah untuk kemudian dianalisis, dibahas dan disimpulkan hasilnya.

\section{HASIL DAN PEMBAHASAN}

Hasil penelitian yang berupa data kuantitatif terdiri dari motivasi belajar dan kemampuan berpikir kreatif. Hasil uji $N$ Gain berdasarkan skor kuesioner motivasi belajar awal sebelum diberikan perlakuan dan skor kuesioner motivasi belajar akhir setelah diberikan perlakuan digunakan untuk melihat peningkatan motivasi belajar peserta didik antara kelas eksperimen dan kelas kontrol. Adapun hasil analisis uji $\mathrm{N}$-Gain dapat dilihat pada Tabel 2.

Tabel 2. Hasil Analisis Uji N-Gain Motivasi Belajar

\begin{tabular}{lccccc}
\hline Kelas & $\mathbf{N}$ & $\begin{array}{c}\text { Rata- } \\
\text { rata } \\
\text { sebel } \\
\text { um }\end{array}$ & $\begin{array}{c}\text { Rata- } \\
\text { rata } \\
\text { sesud } \\
\text { ah }\end{array}$ & $\begin{array}{c}\text { Rata- } \\
\text { rata } \\
\boldsymbol{N}-\end{array}$ & $\begin{array}{c}\text { Kain } \\
\text { klasifi } \\
\text { kasi }\end{array}$ \\
\hline $\begin{array}{l}\text { Ekspe } \\
\text { rimen } \\
\begin{array}{l}\text { Kon } \\
\text { trol }\end{array}\end{array}$ & 34 & 54,21 & 87,6 & 0,73 & Tinggi \\
\hline
\end{tabular}

Hasil uji $N$-Gain pada Tabel 2 menunjukkan bahwa motivasi belajar peserta didik antara kelas eksperimen dan kelas kontrol memiliki perbedaan. Hasil uji $N$-Gain kelas eksperimen termasuk dalam klasifikasi tinggi. Sedangkan hasil uji $N$-Gain kelas kontrol termasuk klasifikasi sedang. Peningkatan motivasi belajar peserta didik kelas eksperimen yang menggunakan model pembelajaran Treffinger lebih tinggi dibandingkan motivasi belajar peserta didik kelas 
kontrol yang menggunakan pembelajaran konvensional.

Adapun perolehan skor motivasi belajar peserta didik awal dan akhir pada kelas eksperimen dan kelas kontrol dapat dilihat pada Gambar 1.

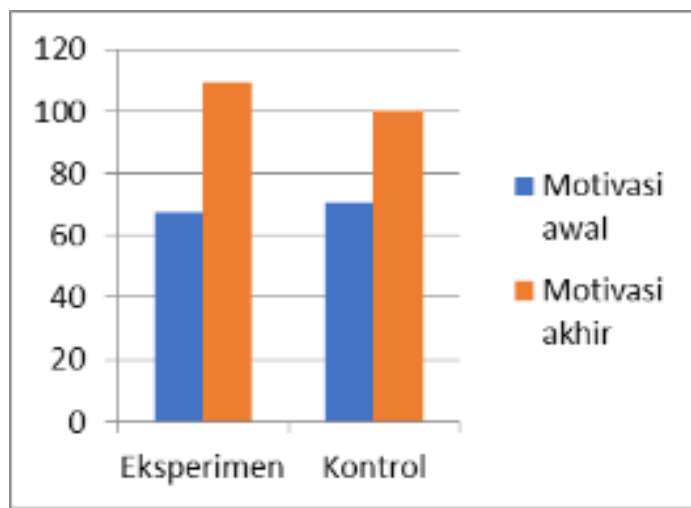

Gambar 1. Grafik Perolehan Skor Ratarata Motivasi Belajar Peserta Didik

Berdasarkan Gambar 1 terlihat bahwa motivasi belajar peserta didik awal sebelum diberikan perlakuan termasuk ke dalam kategori cukup baik, namun setelah diberikan perlakuan baik menggunakan model Treffinger ataupun pembelajaran konvensional motivasi belajar peserta didik meningkat. Namun peningkatan signifikan terjadi pada kelas yang menggunakan model Treffinger. Hal ini karena model pembelajaran Treffinger berpusat pada peserta didik. Pada model pembelajaran ini peserta didik ikut terlibat dalam pembelajaran yang membuat peserta didik dapat mengeksplorasi kemampuannya secara maksimal, sehingga dapat memberikan motivasi belajar peserta didik.

Hasil uji $N$-Gain berdasarkan nilai pretest dan posttest digunakan untuk melihat peningkatan kemampuan berpikir kreatif peserta didik antara kelas eksperimen dan kelas kontrol. Adapun hasil analisis uji $\mathrm{N}$-Gain dapat dilihat pada Tabel 3.

Tabel 3. Hasil Analisis Uji N-Gain Kemampuan Berpikir Kreatif

\begin{tabular}{llllll}
\hline Kelas & $\mathbf{N}$ & $\begin{array}{l}\text { Rata- } \\
\text { rata } \\
\text { Prete } \\
\text { st }\end{array}$ & $\begin{array}{l}\text { Rata- } \\
\text { rata } \\
\text { Postt } \\
\text { est }\end{array}$ & $\begin{array}{l}\text { Rata- } \\
\text { rata } \\
\text { Gain }\end{array}$ & $\begin{array}{l}\text { Klasifi } \\
\text { kasi }\end{array}$ \\
\hline $\begin{array}{l}\text { Ekspe } \\
\text { rimen }\end{array}$ & 34 & 29,91 & 80,35 & 0,72 & Tinggi \\
$\begin{array}{l}\text { Kon } \\
\text { trol }\end{array}$ & 35 & 31,05 & 61,02 & 0,41 & Sedang \\
\hline
\end{tabular}

Hasil uji $N$-Gain pada Tabel 3 menunjukkan bahwa kemampuan berpikir kreatif peserta didik antara kelas eksperimen dan kelas kontrol memiliki perbedaan. Hasil uji $N$-Gain kelas eksperimen termasuk dalam klasifikasi tinggi. Sedangkan hasil uji $\mathrm{N}$-Gain kelas kontrol termasuk klasifikasi sedang. Peningkatan kemampuan berpikir kreatif peserta didik kelas eksperimen yang menggunakan model pembelajaran Treffinger lebih tinggi dibandingkan kemampuan berpikir kreatif peserta didik kelas kontrol yang menggunakan pembelajaran konvensional.

Adapun perolehan skor kemampuan berpikir kreatif peserta didik setiap indikator pada kelas eksperimen dan kelas kontrol dapat dilihat pada Gambar 2.

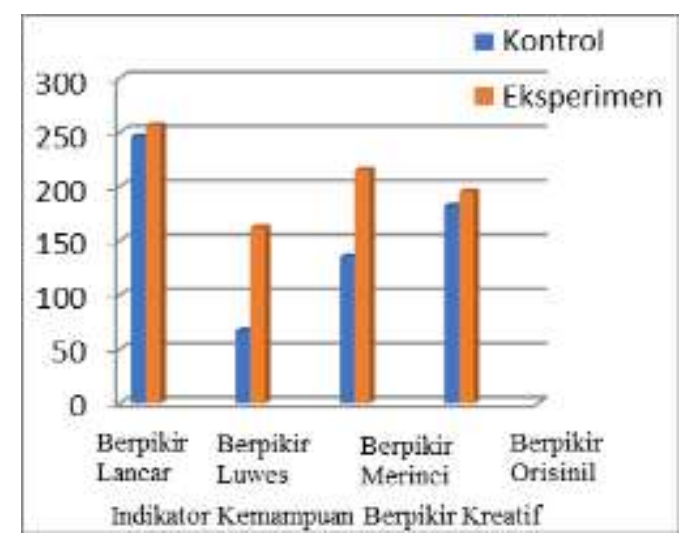

Gambar 2. Grafik Perolehan Skor Kemampuan Berpikir Kreatif Peserta Didik Setiap Indikator 
Berdasarkan Gambar 2 menunjukkan perbedaan pada masing-masing 4 indikator yaitu berpikir lancar, berpikir luwes, berpikir merinci dan berpikir orisinil. Berikut analisis skor pada masing-masing indikator tersebut.

1. Berpikir Lancar

Pada indikator berpikir lancar peserta didik dapat mencetuskan banyak gagasan secara tepat serta dapat menguraikan sesuatu dari sebuah situasi. Pada kelas eksperimen secara keseluruhan peserta didik mampu mencetuskan banyak jawaban secara tepat dan mampu menguraikannya, dan pada kelas kontrol peserta didik pun mampu mencetuskan banyak jawaban secara tepat namun masih ada yang belum mampu menguraikannya. Hal ini dapat dilihat pada dari hasil perolehan skor pada indikator berpikir lancar kelas eksperimen sebesar 256 sedangkan pada kelas kontrol sebesar 246.

Perolehan skor pada indikator berpikir lancar ini merupakan skor tertinggi diantara indikator lainnya, baik di kelas eksperimen maupun kelas kontrol. Tetapi pada kelas eksperimen lebih tinggi dari kelas kontrol walaupun hanya tipis. Hal ini dikarenakan pada kelas eksperimen di tahap basic tools peserta didik diminta untuk mengungkapkan pengetahuannya secara tepat. Peserta didik juga sudah terbiasa menghafal materi, kemudian soal pada indikator ini pun tidak terlalu sulit. Akan tetapi pendidik mengarahkan peserta didik untuk memahami konsep melalui fenomena-fenomena yang ada dalam kehidupan sehari-hari yang berkaitan dengan konsep secara langsung. Oleh karena itu, perolehan skor pada indikator ini tertinggi diantara indikator lainnya.

\section{Berpikir Luwes}

Pada indikator berpikir luwes peserta didik mampu mengubah cara pendekatan, pemikiran dan menyelesaikan masalah dari sudut pandang yang berbeda. Pada kelas eksperimen sebagian peserta didik sudah mampu menyelesaikan suatu masalah dari berbagai sudut pandang serta mampu mengaitkan dengan teori-teori, namun masih ada beberapa peserta didik yang belum mampu. Sedangkan pada kelas kontrol hampir sebagian besar peserta didik belum mampu menyelesaikan suatu masalah dari berbagai sudut pandang serta belum mampu mengaitkan dengan teori-teori. Hal ini dapat dilihat dari perolehan skor pada indikator berpikir luwes kelas eksperimen sebesar 162 sedangkan pada kelas kontrol 67.

Perolehan skor pada indikator berpikir luwes menjadi skor terendah dari indikator lainnya, baik di kelas eksperimen maupun kelas kontrol. Akan tetapi pada kelas eksperimen memperoleh skor lebih tinggi dari kelas kontrol, dapat dilihat juga perbedaan dari keduanya sangat signifikan. Hal ini terjadi karena pada pembelajaran menggunakan model Treffinger pada tahap working with real problems, peserta didik diberikan suatu masalah kemudian peserta didik diminta untuk menyelesaikannya secara diskusi kemudian peserta didik juga diminta untuk mengajukan suatu masalah dari berbagai pandangan lainnya. Sedangkan pada kelas kontrol peserta didik hanya diberikan soal-soal latihan biasa tanpa memberikan suatu masalah atau fenomena. 


\section{Berpikir Merinci}

Pada indikator berpikir merinci peserta didik mampu mengembangkan gagasan secara detail. Pada kelas eksperimen sebagian besar peserta didik sudah mampu mengembangkan konsep secara detail, namun masih ada beberapa peserta didik yang belum mampu. Sedangkan pada kelas kontrol hampir sebagian besar peserta didik belum mampu mengembangkan konsep secara detail, dan pada soal matematis peserta didik sudah mengetahui konsepnya menggunakan rumus yang mana tetapi sebagian kecil dari mereka berhenti pada perhitungan matematisnya. Hal ini dapat dilihat dari perolehan skor pada indikator berpikir merinci kelas eksperimen sebesar 215 sedangkan pada kelas kontrol 135.

Perolehan skor pada indikator berpikir merinci kelas eksperimen lebih tinggi dari kelas kontrol, perbedaan keduanya sangat signifikan. Hal ini karena pada kelas eksperimen pada tahap practice with process, peserta didik diminta untuk memahami konsep secara utuh, sehingga ketika ada suatu masalah peserta didik mampu mengembangkannya secara rinci. Sedangkan pada kelas kontrol sebagian peserta didik masih ada yang belum mampu mengembangkan konsep secara detail. Akan tetapi pada soal matematis sebagian besar peserta didik pada kelas eksperimen maupun kontrol sudah mampu menyelesaikannya walaupun masih ada peserta didik yang berhenti pada perhitungan, hal ini kemungkinan mereka belum memahami konsep matematika dengan baik.

\section{Berpikir Orisinil}

Pada indikator berpikir orisinil peserta didik mampu mengungkapkan gagasan baru yang berbeda satu sama lain. Pada kelas eksperimen dan kelas kontrol sebagian besar peserta didik sudah mampu mengungkapkan gagasan mereka sesuai dengan pengetahuan dan pengalaman mereka. Hal ini dapat dilihat dari hasil perolehan skor pada indikator berpikir orisinil kelas eksperimen sebesar 195 sedangkan pada kelas kontrol sebesar 182.

Perolehan skor pada indikator berpikir orisinil kelas eksperimen lebih tinggi dari kelas kontrol. Hal ini karena soal dari indikator berpikir orisinil tersebut tergolong mudah dan pengetahuan serta pengalaman peserta didik yang berkaitan dengan soal yang diberikan tergolong tinggi. Akan tetapi soal pada indikator berpikir orisinil ini pendidik mengarahkan pada penerapan konsep secara tepat. Walaupun masih ada peserta didik yang belum mampu menjawab soal pada indikator berpikir orisinil, tetapi sudah dapat dikatakan peserta didik mampu berpikir orisinil.

Berdasarkan hasil analisa perolehan skor kemampuan berpikir kreatif pada 4 indikator dapat dilihat bahwa perolehan skor terbesar peserta didik adalah pada indikator berpikir lancar baik pada kelas kontrol maupun kelas eksperimen. Sedangkan perolehan skor terendah peserta didik pada indikator berpikir luwes baik pada kelas eksperimen maupun kelas kontrol.

Kemudian untuk menguji seberapa besar pengaruh model pembelajaran Treffinger terhadap motivasi belajar dan kemampuan berpikir kreatif peserta didik, dalam penelitian ini terlebih dahulu dilakukan uji prasyarat untuk analisis data. Uji prasyarat analisis data dalam penelitian ini yaitu uji normalitas 
menggunakan uji Liliefors dan uji homogenitas menggunakan uji Fisher.

Perhitungan uji normalitas motivasi belajar dan kemampuan berpikir kreatif sebagai berikut:

Tabel 4. Hasil Uji Normalitas Kuesioner Motivasi Belajar

\begin{tabular}{lccc}
\hline \multicolumn{2}{c}{ Kelompok } & LHitung & Kesimpulan \\
\hline \multirow{2}{*}{ Eksperi } & Awal & 0,138 & Normal \\
men & Akhir & 0,086 & Normal \\
\hline \multirow{2}{*}{ Kontrol } & Awal & 0,068 & Normal \\
& Akhir & 0,100 & Normal \\
\hline
\end{tabular}

Berdasarkan data hasil uji normalitas kuesioner motivasi belajar peserta didik pada Tabel 4 dapat diambil kesimpulan dengan cara membandingkan hasil $\mathrm{L}_{\text {tabel }}$ dengan Lhitung. Pada kelas eksperimen $\mathrm{L}_{\text {tabel }}=0,152$ dengan $\mathrm{L}_{\text {hitung }}$ motivasi belajar peserta didik awal 0,138 dan Litung $_{\text {ha }}$ motivasi belajar peserta didik akhir 0,086. Sedangkan pada kelas kontrol $\mathrm{L}_{\text {tabel }}=$ 0,150 dengan Lhitung motivasi belajar peserta didik awal 0,068 dan $\mathrm{L}_{\text {hitung }}$ motivasi belajar peserta didik akhir 0,100.

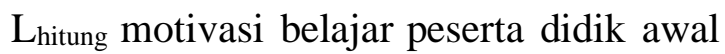
dan akhir pada kelas eksperimen dan kelas kontrol < $\mathrm{L}_{\text {tabel }}$. Sehingga dapat disimpulkan bahwa data motivasi belajar peserta didik awal dan akhir pada kelas eksperimen dan kelas kontrol terdistribusi normal.

Tabel 5. Hasil Uji Normalitas Kemampuan Berpikir Kreatif

\begin{tabular}{llll}
\hline \multicolumn{2}{c}{ Kelompok } & LHitung & Kesimpulan \\
\hline \multirow{2}{*}{ Eksperi } & Pretest & 0,082 & Normal \\
men & Posttest & 0,105 & Normal \\
\hline \multirow{2}{*}{ Kontrol } & Pretest & 0,105 & Normal \\
& Posttest & 0,094 & Normal \\
\hline
\end{tabular}

Berdasarkan data hasil uji normalitas kemampuan berpikir kreatif peserta didik pada Tabel 5 dapat diambil kesimpulan dengan cara membandingkan hasil $\mathrm{L}_{\text {tabel }}$ dengan Lhitung. Pada kelas eksperimen $\mathrm{L}_{\text {tabel }}=0,152$ dengan $\mathrm{L}_{\text {hitung }}$ pretest kemampuan berpikir kreatif 0,082 dan Lhitung posttest 0,105 . Sedangkan pada kelas kontrol $\mathrm{L}_{\text {tabel }}=0,150$ dengan $\mathrm{L}_{\text {hitung }}$ pretest kemampuan berpikir kreatif 0,105 dan $\mathrm{L}_{\text {hitung }}$ posttest 0,094. L L hitung kemampuan berpikir kreatif peserta didik pretest dan posttest pada kelas eksperimen dan kelas kontrol < $\mathrm{L}_{\text {tabel. }}$ Sehingga dapat disimpulkan bahwa data pretest dan posttest kemampuan berpikir kreatif peserta didik kelas eksperimen dan kelas kontrol terdistribusi normal.

Perhitungan uji homogenitas motivasi belajar dan kemampuan berpikir kreatif sebagai berikut:

Tabel 6. Hasil Uji Homogenitas Kuesioner Motivasi Belajar

\begin{tabular}{|c|c|c|c|}
\hline \multicolumn{2}{|c|}{ Kelompok } & $\mathbf{F}_{\text {Hitung }}$ & Kesimpulan \\
\hline Awal & $\begin{array}{l}\text { Eksperimen } \\
\text { Kontrol }\end{array}$ & 1,088 & Homogen \\
\hline Akhir & $\begin{array}{l}\text { Eksperimen } \\
\text { Kontrol }\end{array}$ & 1,214 & Homogen \\
\hline
\end{tabular}

Berdasarkan data hasil uji homogenitas kuesioner motivasi belajar peserta didik pada Tabel 6 dapat diambil kesimpulan dengan cara membandingkan hasil $\mathrm{F}_{\text {tabel }}=$ 1,777 dengan $F_{\text {hitung. Pada data motivasi }}$ belajar peserta didik awal kelas eksperimen dan kelas kontrol $F_{\text {hitung }}=$ 1,088. Sedangkan pada data motivasi belajar peserta didik akhir kelas eksperimen dan kelas kontrol $\mathrm{F}_{\text {hitung }}=$ 1,214. $F_{\text {hitung }}$ motivasi belajar peserta didik sawal dan akhir pada kelas eksperimen dan kelas kontrol $<\mathrm{L}_{\text {tabel }}=(1,777)$. Sehingga dapat disimpulkan bahwa data motivasi belajar peserta didik awal dan akhir pada kelas eksperimen dan kelas kontrol memiliki varian yang sama atau homogen. 
Tabel 7. Hasil Uji Homogenitas Kemampuan Berpikir Kreatif

\begin{tabular}{llcl}
\hline Kelompok & F Hitung & Kesimpulan \\
\hline \multirow{3}{*}{ Pretest } & Eksperi & & \\
& men & 1,150 & Homogen \\
& Kontrol & & \\
\hline \multirow{3}{*}{ Posttest } & $\begin{array}{l}\text { Eksperim } \\
\text { en }\end{array}$ & \multirow{2}{*}{1,594} & Homogen \\
& Kontrol & & \\
\hline
\end{tabular}

Berdasarkan data hasil uji homogenitas kemampuan berpikir kreatif peserta didik pada Tabel 7 dapat diambil kesimpulan dengan cara membandingkan hasil $\mathrm{F}_{\text {tabel }}=$ 1,777 dengan $F_{\text {hitung. }}$ Pada data pretest kemampuan berpikir kreatif kelas eksperimen dan kelas kontrol $F_{\text {hitung }}=$ 1,150. Sedangkan data posttest kelas eksperimen dan kelas kontrol $F_{\text {hitung }}$

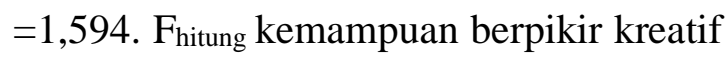
peserta didik pretest dan posttest kelas eksperimen dan kelas kontrol $<\mathrm{L}_{\text {tabel }}=$ (1,777). Sehingga dapat disimpulkan bahwa data pretest dan posttest pada kelas eksperimen dan kelas kontrol memiliki varian yang sama atau homogen.

Setelah data diketahui terdistribusi normal dan homogen untuk menguji hipotesis menggunakan uji t. Berikut hasil perhitungan uji t:

Tabel 8. Hasil Uji Hipotesis Kuesioner

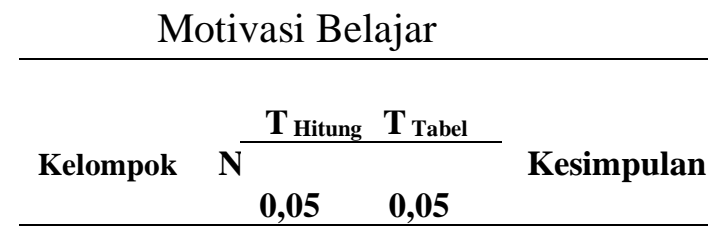

\begin{tabular}{lllll} 
Eksperim & 3 & & & \\
en & 4 & & & \\
& & 6,019 & 1,996 & $\begin{array}{l}\text { Ada } \\
\text { pengaruh }\end{array}$ \\
Kontrol & 3 & & & \\
& 5 & & & \\
\hline
\end{tabular}

Berdasarkan Tabel 8 data hasil uji hipotesis motivasi belajar peserta didik kelas eksperimen dan kelas kontrol yaitu $\mathrm{t}$ hitung $>\mathrm{t}$ tabel $(6,019>1,996)$, artinya terdapat pengaruh model pembelajaran Treffinger pokok bahasan bunyi terhadap motivasi belajar peserta didik.

Tabel 9. Hasil Uji Hipotesis Kemampuan Berpikir Kreatif

\begin{tabular}{|c|c|c|c|c|}
\hline \multirow{2}{*}{ Kelompok } & \multirow{2}{*}{$\mathbf{N}$} & $\begin{array}{l}\text { T } \\
\text { Hitung } \\
\end{array}$ & $\begin{array}{c}\mathbf{T} \\
\text { Tabel } \\
\end{array}$ & \multirow{2}{*}{ Kesimpulan } \\
\hline & & $\mathbf{0 , 0 5}$ & $\mathbf{0 , 0 5}$ & \\
\hline Eksperimen & 34 & \multirow{2}{*}{7,589} & \multirow{2}{*}{1,996} & \multirow{2}{*}{$\begin{array}{l}\text { Ada } \\
\text { pengaruh }\end{array}$} \\
\hline Kontrol & 35 & & & \\
\hline
\end{tabular}

Berdasarkan Tabel 9 data hasil uji hipotesis kemampuan berpikir kreatif peserta didik kelas eksperimen dan kelas kontrol yaitu $t_{\text {hitung }}>t_{\text {tabel }}(7,589>1,996)$, artinya terdapat pengaruh model pembelajaran Treffinger pokok bahasan bunyi terhadap kemampuan berpikir kreatif peserta didik.

Hasil keterlaksanaan model pembelajaran Treffinger pada tiga kali pertemuan dapat dilihat pada Tabel 10 .

Tabel 10. Hasil Observasi Keterlaksanaan Model Pembelajaran

\begin{tabular}{|c|c|c|c|}
\hline \multicolumn{4}{|c|}{ Treffinger } \\
\hline Pertemuan & $\begin{array}{l}\text { Jumlah } \\
\text { skor } \\
\text { pengam } \\
\text { at }\end{array}$ & $\begin{array}{l}\text { Persen } \\
\text { tase }\end{array}$ & Kategori \\
\hline $\mathrm{Ke}-1$ & 80 & $89 \%$ & $\begin{array}{l}\text { Sangat } \\
\text { Baik }\end{array}$ \\
\hline $\mathrm{Ke}-2$ & 82 & $91 \%$ & $\begin{array}{l}\text { Sangat } \\
\text { Baik }\end{array}$ \\
\hline $\mathrm{Ke}-3$ & 82 & $91 \%$ & $\begin{array}{l}\text { Sangat } \\
\text { Baik }\end{array}$ \\
\hline Jumlah & 184 & $\begin{array}{l}90,33 \\
\%\end{array}$ & $\begin{array}{l}\text { Sangat } \\
\text { Baik }\end{array}$ \\
\hline
\end{tabular}

Berdasarkan dari ketiga pertemuan maka persentase rata-rata hasil observasi sebesar 90,33\%, sehingga dapat disimpulkan bahwa pada kelas eksperimen keterlaksanaan model 
pembelajaran Treffinger terlaksana dengan baik.

Temuan pada penelitian ini mendukug beberapa penelitian sebelumnya bahwa pemberian model Treffinger dapat meningkatkan motivasi dan kemampuan berpikir kreatif peserta didik (Ifana \& Putra, 2015; Rahmawati \& Kurniawan, 2015; Rosiyanti \& Wijayanti, 2015). Adanya penelitian ini di harapkan dapat memperbaiki kualitas pendidikan di Indonesia.

\section{SIMPULAN DAN SARAN}

Berdasarkan hasil penelitian diperoleh bahwa terdapat pengaruh model Treffinger untuk pokok bahasan bunyi terhadap motivasi belajar peserta didik dengan nilai $t_{\text {hitung }}=6,019$ dan $t_{\text {tabel }}=$ 1,996 sehingga $t_{\text {hitung }}>t_{\text {tabel }}(6,019>1,996)$. Terdapat pengaruh model Treffinger untuk pokok bahasan bunyi terhadap kemampuan berpikir kreatif peserta didik dengan nilai $t_{\text {hitung }}=7,589$ dan $t_{\text {tabel }}=1,996$ sehingga $t_{\text {hitung }}>t_{\text {tabel }}(7,589>1,996)$. Maka dapat disimpulkan bahwa terdapat pengaruh model Treffinger untuk pokok bahasan bunyi terhadap motivasi belajar dan kemampuan berpikir kreatif peserta didik. Peneliti selanjutnya sebaiknya penilaian kemampuan berpikir kreatif selain menggunakan tes soal dilakukan dengan observasi secara individu dengan beberapa observer ( 1 observer dalam satu kelompok) agar mengetahui secara efektif kemampuan berpikir kreatif peserta didik.

\section{DAFTAR PUSTAKA}

Annuuru, T. A., Johan, R. C., \& Ali, M. (2017). Peningkatan Kemampuan Berpikir Tingkat Tinggi Dalam Pelajaran Ilmu Pengetahuan Alam Peserta Didik Sekolah Dasar Melalui Model Pembelajaran Treffinger. Jurnal Edutcehnologia, 3(2).
Dewi, P. S. (2016). Perspektif Guru Sebagai Implementasi Pembelajaran Inkuiri Terbuka dan Inkuiri Terbimbing terhadap Sikap Ilmiah dalam Pembelajaran Sains. Tadris: Jurnal Keguruan Dan Ilmu Tarbiyah, 1(2), 179-186.

Harjono, A., Makhrus, M., Savalas, L. R. T., \& Rasmi, D. A. C. (2019). Pelatihan Pengembangan Perangkat Pembelajaran IPA untuk Mendukung Kesiapan Guru Sebagai Role Model Keterampilan Abad 21. Jurnal Pendidikan Dan Pengabdian Masyarakat, 2(3), 343-347.

Hwang, G. J., Sung, H. Y., \& Chang, H. (2017). Effects of concept-mappingbased interactive e-books on active and reflective-style students' learning performances in junior high school law courses. Interactive Learning Environments, 25(7), 877888.

https://doi.org/10.1080/10494820.20 16.1224253

Hwang, G., Sung, H., \& Chang, H. (2016). Pengaruh berbasis konseppemetaan interaktif e-buku tentang pertunjukan pembelajaran aktif dan reflektif-gaya siswa dalam kursus hukum SMP. Pembelajaran Interaktif Lingkungan, 4820(September). https://doi.org/10.1080/10494820.20 16.1224253

Idris, M. (2016). The Impact of Supervision, Motivation, and Work Ethic on Teachers' Professional Competence: A Case Study of Private Islamic High School Teachers. International Journal of Human Resource Studies, 6(1), 147158.

Idrus Alhaddad. (2014). Peningkatan Kemampuan Komunikasi dan Self Regulated Learning Matematis Mahasiswa Melalui Pembelajaran Model Treffinger. Jurnal Matematika Dan Pendidikan 
Matematika, 3(2).

Ifana, S. Y., \& Putra, D. F. (2015). Pengaruh Model Pembelajaran Treffinger Terhadap Kemampuan Berfikir Kritis Mahasiswa Universitas Kanjungruhan Malang. Jurnal Pendidikan Geografi, 2.

Irwandani, I., \& Rofiah, S. (2015). Pengaruh Model Pembelajaran Generatif Terhadap Pemahaman Konsep Fisika Pokok Bahasan Bunyi Peserta Didik MTs Al-Hikmah Bandar Lampung. Jurnal Ilmiah Pendidikan Fisika Al-Biruni, 4(2), 165-177.

Irwandani, Latifah, S., Asyhari, A., Muzannur, \& Widayanti. (2017). Modul Digital Interaktif Berbasis Articulate Studio'13: Pengembangan pada Materi Gerak Melingkar Kelas X. Jurnal Ilmiah Pendidikan Fisika Al-Biruni, 6(2), 221-231.

https://doi.org/10.24042/jipfalbiruni. v6i2.1862

Krismiyati. (2017). Pengembangan Sumber Daya Manusia dalam Meningkatkan Kualitas Pendidikan di SD Negeri Inpres Angkasa Biak. Jurnal Office, 3(1), 43-50.

Mamangkey, L. A. G., Tewal, B., \& Trang, I. (2018). Pengaruh Kecerdasan Intelektual (IQ), Kecerdasan Emosional (EQ), dan Kecerdasan Sosial (SQ) terhadap Kinerja Karyawan Kanttor Wilayah Bank BRI Manado. Jurnal EMBA, 6(4), 3208-3217.

Maula, N., \& Edwar, M. (2014). Pengaruh Kesadaran Merek, Persepsi Kualitas, Asosiasi Merek, Dan Loyalitas Merek Terhadap Keputusan Pembelian Produk Eiger Pada Shop In Shop Di Royal Plaza Surabaya. Jurnal Pendidikan Tata Niaga, 2(1).

Noviyana, H. (2017). Pengaruh Model Project Based Learning Terhadap kemampuan Berfikir Kreatif Matematika Siswa. Jurnal Edumath,
3(2), 110-117.

Rahmawati, L., \& Kurniawan, E. S. (2015). Pengaruh Model Pembelajaran Treffinger Terhadap Kreativitas dan Hasil Belajar Suhu dan Kalor Siswa Kelas X SMA Negeri 3 Purworejo Tahun Pelajaran 2014 / 2015, 7(1), 26-31.

Rita. (2019). The Effect of Learning Methods and Learning Motivation On Indonesian Learning Outcomes Class X Students of Panca Budi Medan High School. BirLE- Journal, 2(1), 132-137.

Rofiqah, S. A., Widayanti, \& Rozaqi, A. (2020). Thinking Aloud Pair Problem Solving (TAPPS) Method : The Effect of Understanding Physics Concepts and Communication in High Schools in Indonesia. In Young Scholar Symposium on Science Education and Environment 2019 (pp. 1-8). Bandar Lampung: Journal of Physics: Conference Series. https://doi.org/10.1088/17426596/1467/1/012066

Rosiyanti, H., \& Wijayanti, E. (2015). Implementasi Model Pembelajaran Treffinger Terhadap Hasil Belajar Matematika dan Sikap Siswa. Jurnal Pendidikan Matematika, 1(2), 37-44.

Samsudin, A., Suhandi, A., Rusdiana, D., Kaniawati, I., \& Costu, B. (2016). Investigating The Effectiveness of An Active Learning BasedInteractive Conceptual Instruction (ALBICI) on Electric Field Concept. Asia-Pacific Forum on Science Learning and Teaching, 17(1).

Silvana, T. S., \& Sumbawati, M. S. (2017). Hubungan Antara Motivasi Belajar dan Pembelajaran Berbasis Web pada Mata Pelajaran Simulasi dan Komunikasi Digital di SMK Negeri 2 Surabaya. Jurnal IT-EDU, 2(2), 57-66.

Sugiyono. (2014). Metode Penelitian Kuantitatif Kualitatif dan $R \& D$. Bandung: Alfabeta. 
Supriyono, A. (2018). Pengaruh Kompetensi Pedagogik, Profesional, dan Motivasi Kerja terhadap Kinerja Guru Sekolah Dasar. Jurnal Pendidikan, 18(2), 1-12.

Tanti, T., Jamaluddin, J., \& Syefrinando, B. (2017). Pengaruh Pembelajaran Berbasis Masalah terhadap Beliefs Siswa tentang Fisika dan Pembelajaran Fisika. Jurnal Ilmiah Pendidikan Fisika Al-Biruni, 6(1), 23-36.

https://doi.org/10.24042/jpifalbiruni. v6i1.603

Wahyuni, E. E., Sutarto, \& I Ketut Mahardika. (2015). Model Pembelajaran ROPES ( Review , Overview, Presentation, Exercise , Summary ) Disertai Media Audiovisual Terhadap Aktivitas Dan Hasil Belajar Siswa Pada Pembelajaran Fisika Di MAN 1 Jember. Jurnal Artikel Ilmiah Mahasiswa, 1(1).

Widiana, Z. R. W., \& Hernadi, J. (2018). Analisis Penerapan Brainstorming Terhadap kemampuan berfikir Kreatif Dan Berfikir Kritis Siswa Pada Pembelajaran Matematika. Jurnal Mahasiswa Universitas Muhammadiyah Ponorogo, 2, 113122.

Wijaya, Y. ., Sudjimat, D. ., \& Nyoto, A. (2016). Transformasi Pendidikan Abad 21 Sebagi Tuntutan Pengembangan Sumber Daya Manusia di Era Global. In Prosiding Seminar Nasional Pendidikkan Matematika (p. 2528-259x). Malang: Universitas Kanjuruhan Malang. 